\title{
Protocol
}

\section{Total RNA Extraction from Tardigrades}

Thomas C. Boothby ${ }^{1}$

Department of Chemistry, University of North Carolina at Chapel Hill, Chapel Hill, North Carolina 27599

Purification of high-quality total RNA from specimens is essential for many molecular techniques. In tardigrades (water bears), disruption of the cuticle is an important step in obtaining a good yield that is representative of all tissues of the animal. As with all single-stranded RNA methods, sterile technique, proper storage conditions, and handling are required for maintaining the quality and integrity of the material. This procedure will result in high-quality total RNA suitable for downstream applications such as cDNA synthesis, reverse transcriptase-polymerase chain reaction (RT-PCR), RNAseq library generation, and northern blots.

MATERIALS

Reagents

It is essential that you consult the appropriate Material Safety Data Sheets and your institution's Environmental Health and Safety Office for proper handling of equipment and hazardous materials used in this protocol.

Equipment

Benchtop centrifuges (set to room temperature and $4^{\circ} \mathrm{C}$ )

Liquid nitrogen

Microcentrifuge tubes, low-retention (Fisher Scientific 02-681-320)

Pasteur pipettes, glass

Pestles for 1.5-mL microcentrifuge tubes (USA Scientific 1415-5390)

${ }^{1}$ Correspondence: tboothby@gmail.com

From the Emerging Model Organisms collection.

(C) 2018 Cold Spring Harbor Laboratory Press

Cite this protocol as Cold Spring Harb Protoc; doi:10.1101/pdb.prot102376 
T.C. Boothby

This method was originally derived from a protocol for RNA extraction from C. elegans embryos provided by Erin Osborne Nishimura. It was further adapted from the methods described by Boothby et al. (2017).

1. Collect tardigrades in their culture medium (spring water) in a low-retention microcentrifuge tube.

2. Centrifuge the samples at $4500 \mathrm{~g}$ for $3 \mathrm{~min}$ at room temperature to pellet the tardigrades.

3. Remove as much of the supernatant as possible without disrupting the pellet, and discard this liquid.

4. If necessary, pool multiple pellets into one tube using a micropipette or glass Pasteur pipette, and centrifuge again as described in Step 2.

5. Resuspend the pellet in $100 \mu \mathrm{L}$ of TRIzol (prechilled at $4^{\circ} \mathrm{C}$ ).

6. Place a new, sterile plastic pestle in the microcentrifuge tube.

7. Pour liquid nitrogen into a small styrofoam container, and submerge the tube briefly in liquid nitrogen to freeze.

8. Remove the tube from the liquid nitrogen and allow the sample to thaw. As it thaws, crush the sample with the plastic pestle. Use caution, as the frozen sample can easily be lost during this step.

9. Repeat freezing/thawing (Steps 7-8) at least three times.

10. Once the sample is homogenized, wash the plastic pestle over the microcentrifuge tube using 400 $\mu \mathrm{L}$ of TRIzol to recover as much of the sample as possible.

11. Mix the sample by inverting vigorously by hand, and then add $100 \mu \mathrm{L}$ of chloroform.

12. Shake the tube by hand for $20 \mathrm{sec}$, and then incubate for $3 \mathrm{~min}$ at room temperature.

13. Centrifuge the sample at $10000 \mathrm{~g}$ for $18 \mathrm{~min}$ at $4^{\circ} \mathrm{C}$.

14. Transfer the top NON-pink layer to a new microcentrifuge tube. Keep this sample for use in the remainder of the protocol. Do not transfer any of the pink or white transitional layer.

15. Add an equal volume $(600 \mu \mathrm{L})$ of $100 \% \mathrm{EtOH}$ to the sample from Step 14 .

This sample will now be used with QIAGEN's RNeasy Mini Kit.

16. Load the sample into an RNeasy MINI spin column.

17. Centrifuge the column at $8000 \mathrm{~g}$ for $30 \mathrm{sec}$ at $4^{\circ} \mathrm{C}$.

18. Discard the column flowthrough.

19. Add $350 \mu \mathrm{L}$ of Buffer RW1 (RNeasy Mini Kit) to the column. Centrifuge at $8000 \mathrm{~g}$ for $30 \mathrm{sec}$ at $4^{\circ} \mathrm{C}$.

20. Discard the column flowthrough.

21. Prepare a DNase Mix ( $1 \mu \mathrm{L}$ of DNase I, $1 \mu \mathrm{L}$ of 10X DNase I Reaction Buffer, $8 \mu \mathrm{L}$ of RNase-free $\mathrm{H}_{2} \mathrm{O}$ ).

22. Add $10 \mu \mathrm{L}$ of DNase Mix to the column. Incubate the column for $15 \mathrm{~min}$ at room temperature.

23. Add $350 \mu \mathrm{L}$ of Buffer RW1 to the column. Centrifuge at $8000 \mathrm{~g}$ for $30 \mathrm{sec}$ at $4^{\circ} \mathrm{C}$.

24. Transfer the column to a new collection tube (RNeasy Mini Kit).

25. Add $500 \mu \mathrm{L}$ of Buffer RPE (RNeasy Mini Kit) to the column. Centrifuge at $8000 \mathrm{~g}$ for $2 \mathrm{~min}$ at $4^{\circ} \mathrm{C}$.

26. Discard the flowthrough and centrifuge again at $8000 \mathrm{~g}$ for $1 \mathrm{~min}$ at $4^{\circ} \mathrm{C}$.

27. Place the column in a new centrifuge tube.

28. Add $30 \mu \mathrm{L}$ of RNase-free $\mathrm{H}_{2} \mathrm{O}$ to the column.

29. Incubate the column for $2 \mathrm{~min}$ at room temperature. 
30. Centrifuge the column for $1 \mathrm{~min}$ at $8000 \mathrm{~g}$ at room temperature.

31. Pipette the flowthrough collected in the microcentrifuge tube back onto the column filter.

32. Repeat Steps 29 and 30.

33. Keep the flowthrough (RNA) on ice and use immediately, or store at $-80^{\circ} \mathrm{C}$.

\section{ACKNOWLEDGMENTS}

T.C.B. is supported by the Simons Foundation in conjunction with the Life Sciences Research Foundation and by NASA grant NNX15AB44G.

\section{REFERENCES}

Boothby TC, Tapia H, Brozena AH, Piszkiewicz S, Smith AE, Giovannini I, Rebecchi L, Pielak GJ, Koshland D, Goldstein B. 2017. Tardigrades use intrinsically disordered proteins to survive desiccation. Molecular Cell 65: 975-984.
McNuff R. 2018. Laboratory culture of Hypsibius exemplaris. Cold Spring Harb Protoc doi:10.1101/pdb.prot102319. 


\section{Total RNA Extraction from Tardigrades}

Thomas C. Boothby

Cold Spring Harb Protoc; doi: 10.1101/pdb.prot102376

\begin{tabular}{rc}
\hline $\begin{array}{r}\text { Email Alerting } \\
\text { Service }\end{array}$ & Receive free email alerts when new articles cite this article - click here. \\
\hline $\begin{array}{r}\text { Subject } \\
\text { Categories }\end{array}$ & Browse articles on similar topics from Cold Spring Harbor Protocols. \\
& Emerging Model Organisms (321 articles) \\
& Molecular Biology, general (1293 articles) \\
& RNA (317 articles) \\
& RNA Purification (76 articles) \\
& RNA, general (269 articles) \\
\hline
\end{tabular}

